\title{
Analysis of Some Factors Affecting Market Patronage in Osun State, Nigeria
}

\author{
F. K. Omole \\ Department of Urban and Regional Planning, \\ Federal University of Technology, Akure, Nigeria. \\ Tel:+234-803-453-9896Ｅmail: fkyomole@yaho.co.uk \\ Accepted: April 1, $2012 \quad$ Published: May 15, 2012 \\ URL: http://dx.doi.org/10.5430/ijba.v3n3p16
}

Received: March 13, 2012

doi:10.5430/ijba.v3n3p16

\begin{abstract}
Human settlements are made up of parts, which work together as a system. A major part of the system is the 'market,' whose functionality is found to be influenced by some factors such as mode of transport, consumers' income, sex, age, occupation, markets distance, location and item(s) on sales among others. The use of questionnaire, inventory survey and documentary analysis were employed for this study and the data were subjected to univariate, bivariate and multivariate analyses. Recommendations include; opening up of market roads for the free flow of goods and services, conduct of market survey to determine among other things shop needs and requirements so as to encourage patronage, expansion and general development of the state.
\end{abstract}

Keywords: Market Patronage, Stores, Commodity, Distance, Travel Time and Linkages

\section{Introduction}

Market, as used in this study, connotes an authorized public concourse of buyers and sellers of commodities meeting at a place more or less strictly limited or defined at an appointed time (Omole, 2002; Hodder et al, 1969). Market centres are fundamental to the economic, social, cultural, religious and political life of people. This has been unequivocally presented by Onyemelukwe, 1974; Adalemo, 1979; Sada et al, 1979 among others.

It is believed in many quarters that markets grow anywhere, there are goods to sell and where buyers are available for such goods (Omole, 2002). There is a need to empirically find out the factors responsible for the patronage of market centres. The study area (Osun State), is one of the newly created states in Nigeria, comprising of many towns and villages with quiet a number of market centres. Many of these markets are unknown to many traders and shoppers. This is one of the factors affecting the patronage and growth of market centres in the state. This study therefore tries to find out some of the factors affecting the patronage and growth of market centres in the state and make useful suggestions to improve the general market development.

\section{An Overview of the Study Area}

Osun State was created on August 27, 1991 through the sixth year anniversary broadcast of President Ibrahim Babagida. The state was one of the nine new states created at that time. Before this time, the state was part of the old Oyo State. Most of the towns and villages in Osun State of today are as old as the country itself (Osun State Pub., 1997). The state capital is Osogbo, which is a local government area on its own. In all, a total of thirty local government council areas constitute the state. Among the major towns in the state are Ilesha, Ife, Ede and Ejigbo.

The state has a total land area of 8602 square kilometers and shares boundary with Kwara State in the North, Oyo in the West, Ogun and Ondo in the South and Ekiti State on East. The National Population Figure of 2006 put the state population at 3,423535. Osun State experiences a tropical climate while the local vegetation is the lowland rainforest type.

\section{Methodology}

This research is an extract from a wider research carried out in Osun State. The deductions are from the thirty local government areas of Osun State. Precisely out of the 253 market centres identified in the state, sixty of them (23.7\%) were surveyed with the aid of questionnaire administration responded to by 300 shoppers and 420 market traders. This was backed up with a separate questionnaire administered to the thirty local government area council offices in the state 
and also an inventory survey, which identified the geographical sites of the market centres and their condition. Data were subjected to univariate, bivariate and multivariate analyses to know the relationship between and among the variables investigated.

\section{Literature Perspective}

Markets are man-made features established for the use of man (Omole, 2002). The work of scholars particularly that of Filani et al, 1976; Nwafor, 1982; Sada et al, 1978; Eben-Saleh 1999 among others agree with this assertion. They went further to identify two basic classes of market places as daily and periodic market which were further sub-classified as; morning, full-day, night, periodic, provincial and inter kingdom markets. Nwafor (1982) held the view that a daily market requires the existence of many full-time traders and that it is a more convenient type of market in that it provides daily needs to the people on daily basis. Along this line, Holder et al (1969); Hill, (1966); and Iloje, (1976) noted that it is perhaps because of the importance and significance of daily markets that very large towns in Nigeria have at least one large daily market. Iloeje (1976) and Sada et al (1979) as at the time of their studies observed that Lagos had at least seven daily markets; Ibadan had ten, while each of Kano, Aba and Onitsha had two. Majority of the villages on the other hand had periodic markets, which usually hold at four or eight day's intervals.

Besides the issue of classification of markets, the significance of market centres as a man-made feature in the development of towns and man in general deserves an intensive study. For instance, the role of markets as observed by Mellassoux (1971) is of note especially in Yoruba land, particularly as it relates to the study area (Osun State) where the use of markets as meeting places for the perpetuation of lineage rights and obligations were noted.

Similarly, Bromlay (1971) saw the market place as a place, which provides opportunity to meet one's friends and kinsmen for the exchange of news and gossip. Belshaw (1965) argued convincingly on the political roles and relevance of market places. He stressed that the political weight of political parties are tested in market places. Olorunfemi (1999) re-echoed the work of Belshaw (op cit) by saying that market places serve as avenue for political competition in search of political power. This was apparent according to her, among the Arewa people of Niger Republic, where competition for political power, for authority and legitimacy of a ruler is affirmed. The argument according to her is that market places afford a physical regrouping of social entity that has formally dispersed.

Onyemelukwe (1974) was of the view that the growth of Onitsha (a Nigerian Commercial Centre) was influenced by the trading activities. Along this line, Adalemo (1979) amplified the fact that market places are fundamental points of economic life and that traditional market system in Nigeria represents an articulation of spatial linkages which had been neglected in the post-independence development, such as the building of transport routes to link settlements. He argued that despite the lack of recognition given to the development of market centres in the post-independence period, market centres still strive to perform integrative functions by providing the link between the production and consumption centres of the economies within which they are located. He agreed that not all the market centres are in urban centres, yet, they act as centres for the diffusion of information to the surrounding areas and regions. Not only this, Bohanna (1962) pointed out that market centres due to their centrality and volume of human population are used for dissemination of information which could be announced by the town crier from the kingship to the communities.

The belief is that once such information is announced at the market centres, it would be disseminated to every part of the town by the population in the market without pains. He went further to say that the spread of knowledge about health matters, vaccination against small pox and other diseases are done most of the times in the market centres. He however disagreed with the view that growth pole idea as conceived in the developed world would not be best suited to the developing countries, because according to him, the growth pole idea superimposes largely alien ideals on urban places and on the indigenous socio-economy. He therefore held to the view that the system of market centres as an approach would be better suited for developmental purposes, because of its articulation and intricate ties with the people.

Apart from the diffusion of information by market centres, Anthonia (1973) asserted that market places are social centres. According to him, a market place is an avenue for courtship, visits, exchange of ideas and other social activities; for dancing, drumming, reuniting and other festivities. He argued that a market day is generally regarded as a social gathering day, apart from the economic activities taking place in the markets. He therefore advised that the social function of market places should be utilized through the provision of organized recreation facilities near the market centres. According to him, this would be of tremendous advantage for the overall social cohesion for the development of the youth-physically and mentally, and would probably be a good forum for the enlightenment of the populace at large.

Religious roles have been also ascribed to the market centres especially in Yoruba land. This role can be vividly looked at from traditional, Islamic and Christian viewpoints. Most markets according to Hodder (1969) have for some time served as places for sacrifice or ritual centres. The purpose for this according to him is to maintain peace at the market 
and in the town in general. In some cases, town spirits are still believed to meet and live in trees in and around the market places. Just as the Yoruba markets are associated with one ritual or the other, so the early Christian and Islam missionaries recognized the value of the market as a place for the propagation of the gospel. For instance, market places are found to be useful for preaching of gospel messages. In the present day, many churches and mosques are located or established close to or adjacent to the market place (Olorunfemi, 1999). She citied the examples of Badagry in Nigeria where the first church was built between two public markets and also in Akure where the central mosque is located opposite the king's market popularly called Oja-Oba.

Segal (1977) in his study of city planning in ancient times noted that the holiness and sacredness of the town is in the market places. He claimed that persons who had been accused of criminal acts were not allowed to enter into "Agora" which is an equivalent of market places in Greek cities and were prevented from entering into 'Forum' in Roman cities which is also an equivalent of market places. This according to him shows the holiness of the market centres. Similarly, in Ibo land in Nigeria, a person who had sworn an oath of innocence at a shrine and had survived a year without dying or becoming seriously ill had the right to parade himself through the market to celebrate his freedom (Olorufemi, op cit).

The discussion above shows the important roles and significance of market places in the development process of towns and the nation in general and these importances can not be overlooked as they affect every segment of our life.

\section{Research Findings and Discussion}

Many factors were found to have influenced market activities and patronage in the study area. Some of these factors are found to have univariate, bivariate and multivariate influence on market patronage. These are discussed below:

\subsection{Age and Occupational Category of Market Patrons}

The variables 'age' and 'occupation' are cross-tabulated to see the effects on each other. Table 1 shows that people from other professions (occupations) apart from the traditional market traders were also engaged in trading in the market centres in Osun State. For instance, out of the 420 market traders interviewed, 36 of them (8.6\%) were farmers who brought their goods directly to the market to sell. Four people $(0.7 \%)$ were teachers. who traded as part-time traders in the market centres, while $346(82.4 \%)$ are full time market traders.

On age, persons between the ages of 22 years and 39 constitute the majority, which are 309 people (72\%) in the age classification of the respondents. People below 21 years of age accounted for $71(17 \%)$ of the total sample. One can deduce from this that a great number of the labour force among the market traders in Osun State are in active age bracket of 22- 30 and $31-39$ years of age. It can also be clearly seen from Table 1 that different classes of people, particular different occupational categories operate in the market centres in Osun State.

\subsection{Sex and Educational Level of Market Patrons}

It was observed that there were more female sellers, 291 (69\%) than male as may be expected in any typical Yoruba settlement (in Nigeria, see Table 2). However, this is not to say that their male counterparts are not involved. As seen from Table 2, male constitutes 129 (31\%) of the sellers. Educationally, it was found that $51 \%$ of these men found in trading in the market have no formal education, those with primary / standard six levels accounted for $34 \%$, Secondary / Grade II $14 \%$, and those with NCE / OND / HSC accounted for $0.7 \%$ of the total sampled. Similarly, the sex and educational level of the shoppers are cross tabulated and the result is presented in Table 3. From this finding, female shoppers are more involved in market patronage $182(61 \%)$ as against the male counterparts which is $18(39 \%)$. This finding is in agreement with other studies in which were reported that women are home-makers and managers, particularly in house keeping (Sada et al, 1978). Educationally, one observes from Table 3 that female with the high level of education have low percentage (5.5\%) among the female folk found in the market. This could perhaps be explained that the group of female gender earning high income could afford to buy in bulk and store at home which invariably reduces their frequency of coming to the market and reduces their number of patronage.

To further buttress this findings, Table 4 shows a cross tabulation of income and patronage. From this Table, it can be seen that people (shoppers) that earn $\$ 12000$ and above make less patronage to the market than those earning $\$ 3,000$ per month. It can perhaps be explained that people (shoppers) that earn higher income can afford to buy in bulk from the market thereby reducing their number of visits to the market. With this observation, one can assert to some level that the higher the income one earns, the less the frequency (trips) one makes to the market centres, judging from this study.

\subsection{Nationality / State of Origin of Market Patrons}

Concerning the nationality of respondents, $99.5 \%$ were found to be Nigerian nationals while only $0.5 \%$ were non-Nigerian. Similarly, $73 \%$ of the respondents were indigenes of the state (Osun State), 17\% were from the neigbouring States like Ekiti, Ondo, Oyo, Kwara, Ogun and Lagos while only 10\% come from far locations. In other 
words, intra-state patronage accounts for $73 \%$ while inter-state patronage accounts for $27 \%$. A lot of commercial activities in the study area predate the creation of the state. For instance, $47 \%$ of the respondents have been in the business 20 years and above, while $73 \%$ started the buying and selling about 10years ago. As discovered, commercial activity is a major employment opportunity in the study area and it cut across different age groups, marital status, occupation and educational groups.

\subsection{Choice of Market Centres, Types and Market-Cycle Days}

Table 5 shows reasons for the choice of market centres. Distance (see asterisk in Table 5.) accounts for $41.3 \%$ followed by 'having all types of goods' $23 \%$, followed by 'easy transport to and from the market centers' $10.3 \%$ and lastly by 'other reasons'. It is clear from this finding that distance plays an important role in the location as well as the choice of market centres by both the market traders and the market shoppers. Evidently, distance is a major factor influencing market patronage. This study shows that the farther the distance of a market centre, the more restricted the market patrons are in patronizing the long distance market centres. Table 5 shows that $41.3 \%$ restricted their movement to the market centres close to their residence. The implication of this is that once their needs cannot be met within the immediate market area, they result to faith. This invariably affects both the sales in far market locations as well affecting the satisfaction level of the people and generally the development in the state.

As a result of unplanned and bad planning in most of the market centres, circulation for pedestrian and vehicular movement pose serious problems. There are always problems for vehicles getting into the market centres for loading and off-loading. Other problems include conflict of vehicular and human traffic in the market centres, leading to insecurity of life in most of the market areas

Concerning type of markets and their cycle-days, it was discovered that a total of 253 market centres were registered in the study area (see Table 6), out of this number, 182 market centres (72\%) are periodic markets with varying market days between 3 to 17 days market intervals. The remaining 71 representing $28 \%$ are daily market centres.

From the empirical result presented in the model summary in Appendix $\mathrm{i}$ shows that coefficient of multiple determination $\mathrm{R}^{2}$ is $=0.713$ which represents the proportion of the variable of the dependent variable that is due to the combined effects of the independent variables. When $\mathrm{R}^{2}(0.713)$ is multiplied by 100 , we get $71.3 \%$, representing the percentage of the variance of the dependent variable that is due to the combined effects of the independent variables that is $\mathrm{X}_{1}$ to $\mathrm{X}_{9}$

The F-statistic or F-ratio is statistically significant at $\alpha$ 0.05 (Appendix ii) Similarly, the T-ratio as presented in Table 7 reveals that only variable $\mathrm{X}_{4}$ and $\mathrm{X}_{7}$, that is, travel time and types of market respectively are the only significant determinants of patronage, while other variables $\mathrm{X}_{1}, \mathrm{X}_{2}, \mathrm{X}_{3}, \mathrm{X}_{5}, \mathrm{X}_{6}, \mathrm{X}_{8}$, and $\mathrm{X}_{9}$ are not significant and as such can be statistically ignored.

Using only the significant variables $\mathrm{X}_{4}$ and $\mathrm{X}_{7}$ to compute the multiple regression model will produce the result below:

$\mathrm{Y}=\mathrm{a}+\mathrm{b}_{4} \mathrm{X}_{4}+\mathrm{b}_{7} \mathrm{X}_{7}$

Patronage $(\mathrm{y})=2.867+(-.111)$ (Travel time) +0.263 (Type of Market)

Of the two significant variable $\mathrm{X}_{4}$ (travel time) and $\mathrm{X}_{7}$ (Type of market) as shown in Table 7, only $\mathrm{X}_{7}$, that is, 'type of markets' contribute positively to the patronage by $26.2 \%$. This finding is true of the periodic markets in that they draw market patrons from both within and far away locations to the market centres. On the other hands, variable $\mathrm{X}_{4}$ (Travel time) makes a small negative contribution to patronage.

Based on this finding, prediction about the patronage can be made. With the number of periodic markets, that is 182 (See Table 6.) and with the average Travel time of 1 hour, the patronage can be predicted using the regression equation as shown in equation 1.

Patronage $=2.867+(-.111(1))+0.263(182)$

$$
=2.867-.111+47.87
$$

Patronage $=50.622$

This reveals that the higher the number of periodic markets, the less the Travel time will be, (in that people might now switch over to periodic markets that are located closer to them, (if there are options for them to do so). The increase in the number of the periodic market serves as intervening opportunity, thereby reducing the distance to be traveled.

\subsection{Effects of Socio-Economic Characteristics on Patronage}

The dependent variable (patronage) is regressed against the following independent variables. 
$\mathrm{X}_{1}=\operatorname{Sex}$

$\mathrm{X}_{2}=$ Age of respondent

$\mathrm{X}_{3}=$ Education level

$\mathrm{X}_{4}=$ Religion

$\mathrm{X}_{5}=$ Income

$\mathrm{X}_{6}=$ Occupational Categorization.

The empirical result of the regression model is presented in Table 8 below:

From the empirical result presented in Appendix iii, the coefficient of multiple determination $\mathrm{R}_{2}$ is 0.606 which represent the proportion of the dependent variable that is due to the combined effects of the independent variables $\mathrm{X}_{1}$ to $\mathrm{X}_{6}$ When $\mathrm{R}_{2}(0.606)$ is multiplied by 100 , we have approximately $61 \%$ representing the patronage of dependent variable that is due to the combined effects of the independent variables. From this particular analysis, $61 \%$ of the variables or changes in $\mathrm{Y}$ (patronage) is explained by variables $\mathrm{X}_{1}$ to $\mathrm{X}_{6}$ (i.e. the independent variables).

The F-statistic is 2.948 and it is statically significant at $\alpha 0.05$ (Appendix iv). Similarly, the T-ratio (Table 8 reveals that only variable $\mathrm{X}_{2}$ that is "Age" is significant, while the remaining variables $\mathrm{X}_{1}(\mathrm{Sex}), \mathrm{X}_{3}$ (educational level), $\mathrm{X}_{4}$ (religion), $\mathrm{X}_{5}$ (income) and $\mathrm{X}_{6}$ (occupation) are found to be statistically insignificant and as such, can be ignored at this level.

Using the only significant variable $\mathrm{X}_{2}$ (Age) to compute a simple regression model will produce the result in equation 2

$\mathrm{Y}=\mathrm{a}+\mathrm{b}_{2} \mathrm{X}_{2}$

The only one significant variable $\mathrm{X}_{2}$ that is, 'Age' is discovered to have contributed negatively to the patronage (y) (See table 8). Using the only significant variable $\mathrm{X}_{2}$ (Age) to compute the regression model produces the result in equation 3

$\mathrm{Y}=\mathrm{a}+\mathrm{b}_{2} \mathrm{X}_{2}$

Patronage $(\mathrm{y})=1.868+(-.127)$ Age

From the equation above, prediction concerning the market patronage can be made. For instance, if the number of people in age brackets $22-30$ increases to say 500 people in the market centres, then the regression model becomes:

Patronage $(\mathrm{y})=1.868+(-127)(500)$

$$
1.868-63.5
$$

Patronage $=61.632$

We can see from the above that 'Age' has negative contribution to market patronage. This can be interpreted thus; the older the age of the market patrons, the less their patronage is likely to be to the market centres.

\section{Recommendations and Policy Guidelines}

Evidently, this work has brought to focus the existence and the functionality of market centres in Osun State as a moving force behind population drift to particular areas where markets are located. The potentials and resource in the state markets and the factors influencing market patronage are also revealed.

The following are recommended for adoption and policy implementation:

It is recommended that the state government in conjunction with the Local Government Councils should open -up market roads to encourage the inflow of goods to and from the market areas in the state. It is also of great importance for the state government to persuade the Federal government to take over the construction of some roads in the state, particularly those that link the state with other states in the country (since the state is landlocked, having no access to the sea or international boundary). Among such roads this study is recommending for opening up are, Ife-Igbira-Yekemi-Apoje road linking Ijebu-Igbo in Ogun State. The rehabilitation of Ijebu-jesha, Esa-odo-Ijara-Otan-ile-Igbojo-Iresi roads need attention. Otanayebaju-Ilaorangun roads linking Kwara state among others are also recommended. This recommendation is put forward against the background that 'distance' and 'transport linkages' are variables that were found affecting market patronage. It is also recommended that the National Union of Road Transport Workers (NURTW) in conjunction with the state government and the local government councils should work out the modalities to make vehicles available and assign commercial vehicles to all routes in the state, particularly on the market days. 
Government, particularly the Local Government Councils (LGCs) should carry out a detailed market survey to determine the shop-needs requirements, so that, on regular basis, they can provide more shops/stalls/stores and allocate them on the basis of need.

It is therefore recommended that some percentage of the money realized by LGCs be invested in the physical development of the market centres in the state. This will not only make the market centres aesthetic but it will enhance patronage and bring a trickle down developmental effect to the rural populace and the generality of the people in the state. To this end, government should review the existing environmental laws and equip the State Environmental Protection Agency with machine/vehicles for easy evacuation of waste from the market centres (because the local governments alone cannot cope with the collection and management of wastes as spelt out in the constitution). This recommendation is based on the finding that environmental condition of the market centres is a factor affecting patronage. The choice of a suitable location as well as the layout of market units - (shops/stalls/stores) furnished with adequate infrastructural facilities should constantly be the target of the planning process. Lack of proper execution zeal which has plagued and destroyed many developmental efforts in the LGAs in the state must be guarded against.

A nine (9) model market centres in the state is also put forward for implementation. This should be taken seriously by both the LGAs and the state government. The nine model market centres are expected to reduce the problem of distance and overall travel cost which was found to be among the factors affecting patronage. This will make every zone and sub-zone of the state accessible. The proposed model market centres is to ensure even spread of development via market planning. As recommended here, the nine model market centres are to be located in the following LGAs: Ife central, Boripe, Ilesha, Ejigbo, Iwo, Irewole, Ikire, Osogbo, Ayedade-Gbongon and Ifetedo (in Atakumosa East). The ideas behind this is that the big existing markets centres in these areas can be upgraded while those not in existence can be built, making every part of the state closer to at least a big market centre, where high order goods can be gotten without much stress. These centres should be accorded the significance as springboards (or market growth centres) for the speedy development of the state)

On area of assistance to the market traders, the state government in conjunction with the LGCs should fashion out avenues through the state Ministry of Trade and Commerce to offer soft loans to the market traders through its registered associations. This measure will help to create employment opportunities particularly among the women folk that are in the majority in the state market centres. This will also reduce idleness among the female gender in the state. Similarly, cooperative societies should be encouraged among the market patrons probably under the guidance of the Ministry of Women Affairs. The market associations in the state could also organize an enlightenment workshop, whereby women can be trained to be self employed. These measures would be a good avenue for loan raising and human resources training particularly the market traders in the state.

It is also important that the LGCs and particularly the State Ministry of Agriculture and Natural Resources and the Ministry of Trade and Commerce should provide a data bank for information on available agricultural produce in the markets, where such produce comes from, their uses, their consumers and possible market outlets for the produce among others. This type of information will assist researchers, governments, investors and the general public.

Acknowledgement: I acknowledge the Federal University of Technology Akure, Nigeria for the sponsorship of this work from its research funding.

\section{References}

Adalemo, A. I. (1979). Small Urban Centers in Nigeria's Development Strategy; The role of rural market centres, small urban centres in Rural development in Africa, African Studies 128-130

Anthonie, Q. O. B. (1967). The supply and Distribution of Yams in Ibadan Market. The Nigeria Journal of Economic and Social Studies . 9(1) 33-49

Belshaw, S. C. (1965). Traditional exchange and modern market Prentice Hall, Eagle wood cliffs

Browley, R.J. (1971). Market in the developing Countries: A Review Geography 1146, 124-132.

Eben-Saleh, M. A. (1999). "Alkalaf: the evolution of the urban built form of a traditional settlement in South-Western Saud-Arabia, in.The International Journal of Building Science and its Application, 34(6) 549-669.

Filani, M. O. \& Richard, P. R. (1976). Period Market Systems and Rural Development. The Ibarapa Case Study, Nigeria Savanna . 149-62 
Hill, P. (1966). Notes on Traditional Market Authority and Market Periodicity in West Africa Journal of African History, 7(1) 195-311

Holder, B. W. \& Ukwu. U. (1969). Markets in West- Africa. Ibadan, University Nigeria Ltd, Chapter 13. 141-14.

Iloeje, N. P. (1976). A new geography of Nigeria Metricated Edition. Longman, Nigeria. Chapter 13. 114-147

Meillassoux, C. (1971). The Development of Indigenous trade and markets in West Africa, London

Nwafor, J. C. (1982). Marketing system and periodic market, Nigeria in Maps . 114

Olorunfemi, A. O. (1999). Problems and Prospects of Commercial Markets in Akure, B. Tech, Thesis, URP, FUT, Akure

Omole, F. K. (2000). Urban Renewal Process: Issues and Strategies, Concept Books, Lagos, 46-59

Omole, F. K. (2002). A spatial distribution of market centres in the development of Osun State, Nigeria, Ph. D Thesis FUTA, Nigeria.

Osun State Publication (OSP). (1992). Osun State the state of the living spring-1 year

Onyemeluke J. O. C. (1974). Some factors in the growth of West Africa Market Town: The example of pre-civil war Onitsha Nigeria Urban Studies 2(1) 47-59

Sada, P. O. \& McNulty. (1978). The Market Traders in the city of Lagos Urbanization and Problems in Nigeria (Ed) Ibadan university press, 63-80

Segal, A. (1977) City Planning in Ancient Times. The Lerner Archaeology Series. Lerner Publications Company, Minneapolis.

Table 1. Occupational Category of Sellers by age (\% in parenthesis)

\begin{tabular}{|c|c|c|c|c|c|c|c|c|c|c|c|}
\hline \multirow[b]{2}{*}{ Age of Respondents } & \multicolumn{11}{|c|}{ Occupation categorization } \\
\hline & 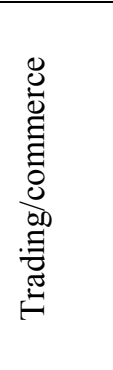 & 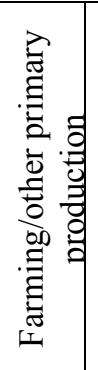 & 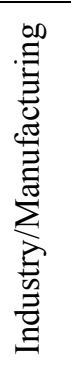 & 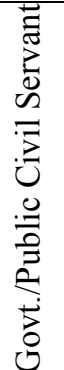 & $\begin{array}{l}\stackrel{\infty}{\Xi} \\
\stackrel{\Xi}{0} \\
\stackrel{\Xi}{\oplus}\end{array}$ & 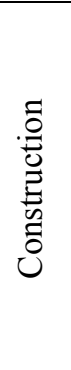 & 泀 & 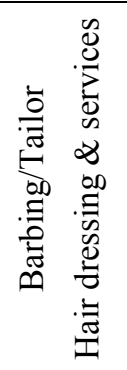 & $\begin{array}{l}\frac{n}{0} \\
\stackrel{ \pm}{0}\end{array}$ & $\stackrel{\vec{\pi}}{0}$ & 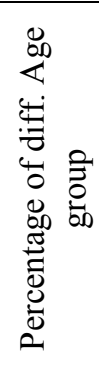 \\
\hline $1-20$ years & $\begin{array}{c}(10 \%) \\
36 \\
(90 \%)\end{array}$ & - & - & - & - & - & - & $\begin{array}{c}(0.2 \%) \\
1\end{array}$ & $\begin{array}{c}(0.7 \%) \\
3\end{array}$ & 40 & 10 \\
\hline $21-30$ & $\begin{array}{c}(44 \%) \\
151 \\
(84 \%)\end{array}$ & 12 & 1 & 1 & $\begin{array}{c}(5 \%) \\
2\end{array}$ & - & - & 4 & 8 & 179 & 42 \\
\hline $31-39$ & $\begin{array}{c}(34 \%) \\
116 \\
(89 \%)\end{array}$ & 7 & - & 1 & - & 3 & - & 2 & 1 & 130 & 31 \\
\hline 40 years and above & $\begin{array}{c}(12 \%) \\
43 \\
(60 \%)\end{array}$ & 17 & 2 & 3 & $\begin{array}{c}(5 \%) \\
2\end{array}$ & - & 1 & - & 3 & 71 & 17 \\
\hline Total & $\begin{array}{c}(82 \%) \\
346\end{array}$ & 36 & 3 & 5 & 4 & 3 & 1 & 7 & 15 & 420 & $100 \%$ \\
\hline Percentage of diff. Occupation & 82.4 & 8.6 & 0.7 & 1.2 & 0.9 & 0.7 & 0.2 & 1.7 & 3.6 & - & $100 \%$ \\
\hline
\end{tabular}


Table 2. Educational level by Sex of Sellers (\% in parenthesis)

\begin{tabular}{|c|c|c|c|c|c|c|c|c|c|}
\hline \multirow[b]{2}{*}{ Sex } & \multicolumn{9}{|c|}{ Educational level } \\
\hline & 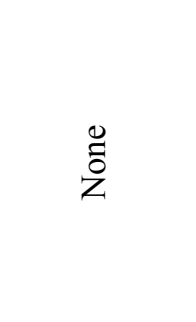 & 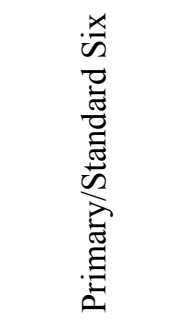 & 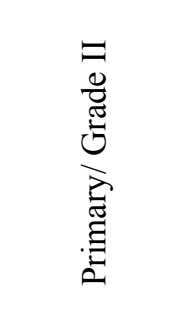 & 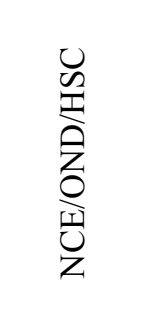 & 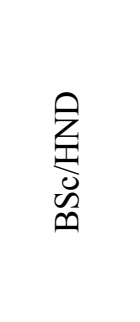 & 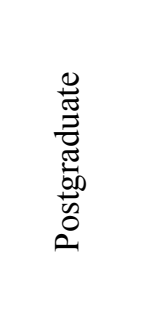 & $\frac{n}{\tilde{\Xi}}$ & $\stackrel{\sqrt[\pi]{0}}{0}$ & 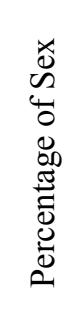 \\
\hline Male & $(51 \%) 66$ & $(34 \%) 44$ & $(14 \%) 18$ & $(0.3 \%) 1$ & 0 & 0 & 0 & 129 & 31.0 \\
\hline Female & $(14 \%) 40$ & $(34 \%) 100$ & $(36 \%) 105$ & $(13 \%) 39$ & $(1.7 \%) 5$ & $(0.3 \%) 1$ & $(0.3 \%) 1$ & 291 & 69.0 \\
\hline Total & $(25.2 \%) 106$ & $(34.3 \%) 144$ & $(29.3 \%) 123$ & $(9.5 \%) 40$ & $(1.2 \%) 5$ & $(0.2 \%) 1$ & $(0.2 \%) 1$ & 420 & $100 \%$ \\
\hline $\begin{array}{l}\text { Percentage } \\
\text { of diff. } \\
\text { Education }\end{array}$ & 25.3 & 34.2 & 29.3 & 9.6 & 1.2 & 0.2 & 0.2 & & $100 \%$ \\
\hline
\end{tabular}

Source: Author's fieldwork (2011)

Table 3. Sex and Educational level of respondents (shoppers) (\%in parenthesis)

\begin{tabular}{|c|c|c|c|c|c|c|c|c|c|}
\hline \multirow[b]{2}{*}{ Sex } & \multicolumn{9}{|c|}{ Educational level } \\
\hline & ஜ̈ & 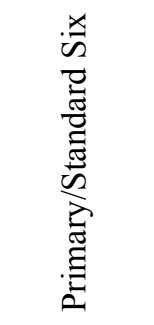 & 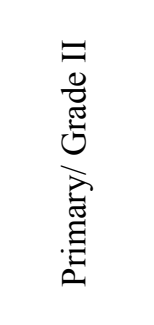 & 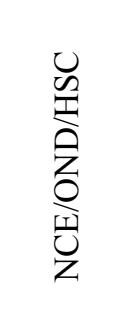 & 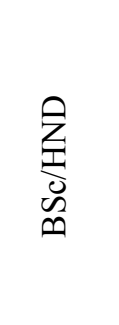 & 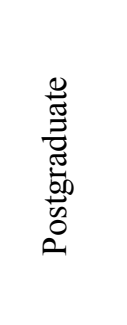 & $\frac{\frac{n}{0}}{\tilde{0}}$ & $\stackrel{\bar{\sigma}}{0}$ & 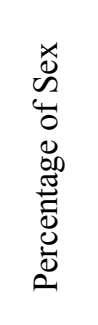 \\
\hline Male & $(35 \%) 44$ & $\begin{array}{c}(16.6 \%) \\
55\end{array}$ & $(11 \%) 13$ & $(5.1 \%) 6$ & 0 & 0 & $(17.2 \%) 2$ & 118 & 39 \\
\hline Female & $\begin{array}{c}(12.6 \%) \\
23\end{array}$ & $(28 \%) 51$ & $\begin{array}{c}(19.7 \%) \\
36\end{array}$ & $\begin{array}{c}(16.5 \%) \\
30\end{array}$ & $\begin{array}{c}(5.5 \%) \\
10\end{array}$ & $\begin{array}{c}(6.5 \%) \\
10\end{array}$ & $\begin{array}{c}(11.0 \%) \\
20\end{array}$ & 182 & 61 \\
\hline Total & 65 & 106 & 49 & 36 & 10 & 12 & 22 & 300 & $100 \%$ \\
\hline $\begin{array}{l}\text { Percentage of } \\
\text { diff. Education }\end{array}$ & 2.2 & 35 & 16 & 12 & 3.4 & 4.1 & 7.4 & & $100 \%$ \\
\hline
\end{tabular}

Source: Author's field work (2011) 
Table 4. Cross-tabulation of income and Patronage of Market Centres

\begin{tabular}{|c|c|c|c|c|c|}
\hline \multicolumn{6}{|c|}{ Variable 2: Patronage } \\
\hline \multicolumn{6}{|c|}{ Number of Visit to Market } \\
\hline Variable1: & Everyday & Once a Week & Once a month & Total & $\begin{array}{c}\text { Percentage of } \\
\text { Total }\end{array}$ \\
\hline $\begin{array}{c}\text { Income: less than } \\
\text { N3000 }\end{array}$ & & & & & \\
\hline Per month & 27 & 68 & 12 & 107 & 35.67 \\
\hline N3001 - 6000 & 34 & 43 & 5 & 82 & 27.33 \\
\hline N6001-9000 & 23 & 34 & 4 & 61 & 20.33 \\
\hline N9001-12000 & 17 & 13 & 3 & 33 & 11.00 \\
\hline Above N12000 & 6 & 9 & 2 & 17 & 5.4 \\
\hline Total & 107 & 1667 & 26 & 300 & $100 \%$ \\
\hline
\end{tabular}

Source: Author's Fieldwork (2011)

Table 5. Choice of Market Centres

\begin{tabular}{|c|c|c|c|}
\hline $\begin{array}{c}\text { Reasons for Choice } \\
\begin{array}{c}\text { Family and friends selling in the } \\
\text { market }\end{array}\end{array}$ & Frequency & Percentage & Rank \\
\hline $\begin{array}{c}\text { Close to residence (distance) } \\
\text { Ethnic-language }\end{array}$ & 124 & 41.3 & 1 \\
\hline $\begin{array}{c}\text { Availability } \\
\text { Reliability of market } \\
\text { (non-Periodic) }\end{array}$ & 1 & 9.3 & 4 \\
\hline $\begin{array}{c}\text { Availability of good stalls/shops to } \\
\text { stay in }\end{array}$ & 11 & 3.7 & 5 \\
\hline $\begin{array}{c}\text { Easy transport to and fro market } \\
\text { Neatness of the market centres }\end{array}$ & 31 & 10.3 & 6 \\
\hline $\begin{array}{c}\text { Having all types of goods (variety of } \\
\text { goods) }\end{array}$ & 5 & 1.7 & 6 \\
\hline I do not know & 69 & 23.0 & 2 \\
\hline Total & 300 & 1.0 & 7 \\
\hline
\end{tabular}

Source: Author's field work (2011) 
Table 6. Major type of markets and market-cycle days in Osun State.

\begin{tabular}{|l|l|l|l|l|}
\hline $\begin{array}{l}\text { Major types of } \\
\text { market }\end{array}$ & Market days & Frequency & Total & Percentage of type \\
\hline & 17 & 1 & & \\
\hline & 15 & 2 & & \\
\hline & 14 & 2 & & \\
\hline Periodic & 8 & 18 & 182 & 72 \\
\hline & 7 & 0 & & \\
\hline & 5 & 155 & & \\
\hline & 3 & 4 & & 28 \\
\hline Daily & Daily & 71 & 71 & $100 \%$ \\
\hline Total & & 253 & 253 & \\
\hline
\end{tabular}

Sources: Author's field work Inventory survey (2011). (2) Osun State Market Women Association.

(v) Empirical result of factors that influence Patronage

The dependent variable ( $\mathrm{y}=$ shoppers patronage) is regressed against the independent variables $\mathrm{X}_{1}$ to $\mathrm{X}_{9}$. The $\mathrm{X}_{1}-\mathrm{X}_{9}$ are independent variables detailed out below,

$\mathrm{X}_{1}=$ Income

$\mathrm{X}_{2}=$ Amount spent at average in the market at once.

$\mathrm{X}_{3}=$ Major items bought.

$\mathrm{X}_{4}=$ Travel time - how long does it take you from your residence

$\mathrm{X}_{5}=$ Available routes linking this market.

$\mathrm{X}_{6}=$ Mode of transport to the Market.

$\mathrm{X}_{7}=$ Type of market

$\mathrm{X}_{8}=$ Environmental assessment of the market in term of neatness.

$\mathrm{Y}=$ Patronage (dependent variable)

Table 7. Analysis of Factors That Influence Market Patronage

\begin{tabular}{|c|c|c|c|c|}
\hline Variable & Coefficient & Standard Error & T-Ratio & Remark \\
\hline Constant & 2.867 & .256 & 11.190 & $\mathrm{~S}$ \\
\hline $\mathrm{X}_{1}$ & .015 & .032 & -.478 & NS \\
\hline $\mathrm{X}_{2}$ & -076 & .045 & -1.690 & NS \\
\hline $\mathrm{X}_{3}$ & .041 & .024 & -1.712 & NS \\
\hline $\mathrm{X}_{4}$ & -111 & .050 & -2.230 & $\mathrm{~S}$ \\
\hline $\mathrm{X}_{5}$ & .0082 & .030 & -.272 & NS \\
\hline $\mathrm{X}_{6}$ & .022 & .032 & .693 & NS \\
\hline $\mathrm{X}_{7}$ & .262 & .056 & -4.662 & $\mathrm{~S}$ \\
\hline $\mathrm{X}_{8}$ & .112 & .066 & -1.698 & NS \\
\hline $\mathrm{X}_{9}$ & 039 & .009 & -.310 & NS \\
\hline \multicolumn{4}{|c|}{$\begin{array}{l}\mathrm{S}=\text { Significant } \\
\mathrm{R}^{2}=0.713 \text { (See Appendix 9 i) } \\
\text { Source: Author's fieldwork (2011). }\end{array}$} & \\
\hline
\end{tabular}


Table 8. Analysis of Socio-economic Characteristics on Patronage

\begin{tabular}{|c|c|c|c|c|}
\hline Variable & Co-efficient & Standard Error & T-Ratio & Remark \\
\hline Constan & 1.868 & 0.134 & 13.896 & $\mathrm{~S}$ \\
\hline $\mathrm{X}_{1}$ & .029 & 0.092 & 0.318 & NS \\
\hline $\mathrm{X}_{2}$ & -.127 & 0.049 & -2.599 & $\mathrm{~S}$ \\
\hline $\mathrm{X}_{3}$ & .023 & 0.024 & -.992 & NS \\
\hline $\mathrm{X}_{4}$ & .113 & 0.076 & 1.476 & NS \\
\hline $\mathrm{X}_{5}$ & .033 & 0.033 & -1.004 & NS \\
\hline $\mathrm{X}_{6}$ & .025 & 0.013 & 1.867 & \\
\hline \multicolumn{5}{|c|}{ Significant $\quad \mathrm{R}^{2}=0.606$ (See Appendix iii) } \\
\hline \multicolumn{2}{|c|}{$\begin{array}{l}\text { NS = Not significant } F= \\
\text { Significant level } 0.05\end{array}$} & (See Appendix & & \\
\hline
\end{tabular}

Source: Author's field work.(2011)

\section{Appendixices}

(i) Model Summary: Regression Analysis Of Factors That Influence Shoppers Patronage

\begin{tabular}{|l|l|l|l|l|l|l|}
\hline & Variables & & R & $\mathrm{R}^{2}$ & $\begin{array}{l}\text { Adjusted } \\
\text { Square }\end{array}$ & $\begin{array}{l}\text { Std. Error of } \\
\text { the Estimate }\end{array}$ \\
\hline 1 & Entered & $\begin{array}{l}\text { Removed } \\
\text { Facilities Available In/around } \\
\text { the Market, Income, Type Of } \\
\text { Market Mode of transport to the } \\
\text { Mark, Environmental Assessment of } \\
\text { the Market in terms of neatness, } \\
\text { available routes /link In the Market, } \\
\text { At average the amount of sales in the } \\
\text { Market, Travel Time: How long does } \\
\text { it take from residence, Major } \\
\text { items bought from the market. }\end{array}$ & & & & \\
\hline
\end{tabular}

a) Dependent Variable: How Often Do You Patronise the Market centres

b) Independent Variables: (Constant), Facilities Available In/Around the Market, Income, Type of market, what is your mode of Transport to the Market,

What is your Environmental assessment of The Market In Term of Neatness, How many available routes link in This Market, At average give the amount you spend in the market at once, Travel time: How long does it take you from residence, Major items bought

(ii) ANOVA

\begin{tabular}{|c|c|c|c|c|c|c|}
\hline Model & & $\begin{array}{l}\text { Sum of } \\
\text { Squares }\end{array}$ & Df & Mean Square & $\mathrm{F}$ & Sig \\
\hline 1. & $\begin{array}{l}\text { Regression } \\
\text { Residual } \\
\text { Total }\end{array}$ & $\begin{array}{l}13.953 \\
97.177 \\
111.130\end{array}$ & $\begin{array}{l}9 \\
290 \\
299\end{array}$ & $\begin{array}{l}1.550 \\
0.335\end{array}$ & 4.627 & .000 \\
\hline
\end{tabular}

a) Dependent Variable: How often Do You Patronise this Market 
b) Independent Variables: (Constant), Facilities Available In/Around The Market, Income, Type Of Market, What Is Your Mode Of Transport To The Market, What Is Your Environmental Assessment Of The Market In Term Of Neatness,. How Many Available Routes Link This Market, At Average Give The Amount You Spend In The Market At Once, Travel Time How Long Does It Take You from Your Residence Major Items Bought

(iii) Model Summary: Effect Of Social-Economic Characteristics Of Shoppers On Patronage

\begin{tabular}{|l|l|l|l|l|l|l|}
\hline & Variable & R & R Square & $\begin{array}{l}\text { Adjusted R } \\
\text { Square }\end{array}$ & $\begin{array}{l}\text { Std Error of the } \\
\text { Estimate }\end{array}$ \\
\hline Model & Entered & Removed & & & & \\
\hline 1. & $\begin{array}{l}\text { Occupational } \\
\text { Categorization, Age Of } \\
\text { Respondent, Religion, } \\
\text { Income, Education } \\
\text { Level, Sex }\end{array}$ & 0.624 & .606 & .038 & .60 \\
\hline
\end{tabular}

a) Dependent Variable: How Often Do You Being Patronize This Market

b) Method: Enter

c) Independent Variables: (constant), Occupational Categorization, Age Of Respondent, Religion, Income, Education Level, Sex

d) All requested variables entered.

(iv) ANOVA

\begin{tabular}{|l|l|l|l|l|l|l|}
\hline Model & & $\begin{array}{l}\text { Sum of } \\
\text { Squares }\end{array}$ & Df & Mean square & F & Sig \\
\hline 1. & Regression & 6.327 & 6 & 1.054 & 2.948 & .008 \\
& Residual & 104.803 & 293 & .358 & & \\
& Total & 111.130 & 299 & & & \\
\hline
\end{tabular}

a) Dependent Variable: How Often Do You Being Patronize This Market

b) Independent Variables: (Constant), Occupational Categorization, Age Of Respondent, Religion, Income, Education Level, Sex

Computer Galley from Author's field work (2008) 